\title{
Follow-up of 13 children after ureterosigmoidostomy
}

\author{
N. J. BAKKER, K. J. vAN DAMME, and H. J. de VOOGT \\ From the Department of Urology, Academisch Ziekenhuis, Rotterdam, the J. A. Cohen Institute for \\ Radiopathology and Radiationprotection, Leiden, and the Department of Urology, Academisch \\ Ziekenhuis, Leiden, the Netherlands
}

\begin{abstract}
Bakker, N. J., van Damme, K. J., and de Voogt, H. J. (1976). Archives of Disease in Childhood, 51, 544. Follow-up of 13 children after ureterosigmoidostomy. Follow-up of 13 children who had had a ureterosigmoid anastomosis $3 \frac{1}{2}$ to 10 years previously and whose initial urogram had been satisfactory, showed that growth was normal and that there was no serious metabolic disorder. In particular wholebody potassium did not differ significantly from normal values (as given by Langham, 1961). Asymptomatic urinary infection is the chief hazard in these cases but is difficult to diagnose and may lead to progressive dilatation of the ureters.
\end{abstract}

We have long held that ureterosigmoidostomy is the most comfortable type of urinary diversion operation for children (Bakker and Cornil, 1972). Serious objections to it have been raised, however, because of late complications such as chronic pyelonephritis, acidosis, depletion of total body potassium, and growth retardation. Acute pyelonephritis may occur and is easily recognizable (Spence, 1966), but chronic pyelonephritis often contributes to progressive renal insufficiency without clinical symptoms or radiological signs. Unfortunately, the impossibility of collecting a proper urine sample makes it difficult to detect a urinary tract infection and to study renal function.

Imbalances of serum sodium, chloride, bicarbonate, and potassium concentrations are readily diagnosed, but serum potassium levels are an unreliable indicator of whole-body potassium, especially in the presence of haemoconcentration or acidosis. Since depletion of body potassium may affect renal function and, in children, retard growth it must be looked for in every patient with a ureterosigmoidostomy, even in the absence of symptoms, hypokalaemia, or radiological evidence of an abnormal upper tract (Stamey, 1956). Although some authors mention retardation of growth as a consequence of ureterosigmoidostomy in children, and attributable to acidosis, potassium depletion, or deteriorating renal function, we could find little information about the growth of children after the operation. We have therefore studied a

Received 5 November 1975. group of children on whom it had been successfully performed.

\section{Patients and methods}

Between 1964 and 1970 we performed ureterosigmoidostomy on 15 children, in 13 because of exstrophy of the bladder, in 1 because of congenital absence of the urethra and bladder neck, and in 1 after radical cystectomy for sarcoma botryoides. Two of the 13 children who had been operated upon for exstrophy of the bladder were omitted from the study, one because severe bilateral hydronephrosis developed within 3 months of the operation, and the other had recurrent attacks of acute pyelonephritis after the operation due to intestinoureteral reflux. Thus the follow-up study was of 13 children, 5 girls and 8 boys.

The children were known to have had a normal or almost normal intravenous pyelogram (IVP) with no intestinoureteral reflux 3 months after the operation. One exception was a girl who had radiological signs of bilateral chronic pyelonephritis before operation. Ages at the time of operation varied from 1 to 10 years; 9 children were aged between 1 and 2 years, 2 between 3 and 4 years, and 2 were aged $4 \frac{1}{2}$ and 10 years respectively. The first follow-up examinations were made in 1971 and the second 2 years later in 1973 . The period between operation and the follow-up in 1973 ranged from 3 years 4 months to 9 years 9 months (Table I).

After operation each child was prescribed alkali and potassium supplements (a mixture of potassium citrate, acetate, and bicarbonate, totalling $44 \mathrm{mEq}$ daily) with prophylactic sulphonamides, but at follow-up it was found that not every child had taken the medication. All the children were leading active lives.

At the 1971 follow-up the serum creatinine, $\mathrm{Na}, \mathrm{K}, \mathrm{Cl}$, and bicarbonate were measured, an IVP was done (a 
TABLE I

Age at operation and length of follow-up in 1973 (cases numbered in order of duration of follow-up)

\begin{tabular}{c|c|c|c}
\hline $\begin{array}{c}\text { Case } \\
\text { no. }\end{array}$ & Sex & $\begin{array}{c}\text { Age at } \\
\text { operation } \\
\text { (years) }\end{array}$ & $\begin{array}{c}\text { Duration of } \\
\text { follow-up } \\
\text { (years) }\end{array}$ \\
\hline 1 & F & $4 \cdot 4$ & $3 \cdot 4$ \\
2 & F & $3 \cdot 11$ & $3 \cdot 5$ \\
3 & M & $1 \cdot 2$ & $3 \cdot 5$ \\
4 & F & $10 \cdot 2$ & $3 \cdot 6$ \\
5 & M & $3 \cdot 7$ & $4 \cdot 2$ \\
6 & M & $1 \cdot 0$ & $4 \cdot 10$ \\
7 & M & $1 \cdot 6$ & $4 \cdot 10$ \\
8 & M & $1 \cdot 6$ & $5 \cdot 0$ \\
9 & F & $2 \cdot 1$ & $5 \cdot 2$ \\
10 & M & $1 \cdot 5$ & $5 \cdot 3$ \\
11 & F & $1 \cdot 3$ & $5 \cdot 4$ \\
12 & M & $1 \cdot 6$ & $9 \cdot 7$ \\
13 & M & $1 \cdot 3$ & $9 \cdot 9$ \\
\hline
\end{tabular}

single film taken 30 minutes after injection of contrast), and the total body potassium estimated. At the followup in 1973 the same investigations were made, and also radiographs of the carpal bones were taken. A history of bouts of fever and loin pain or tenderness was regarded as evidence of acute pyelonephritis. Raised white blood counts or erythrocyte sedimentation rates were ascribed to chronic pyelonephritis.

Whole body potassium was measured with a wholebody radioactivity monitor stationed at Leiden (Damme and Barnhoorn, 1970). This uses four scintillation detectors inside a monitor room with walls of lead $10 \mathrm{~cm}$ thick. Counts were made with the patient prone and supine for 25 minutes in each position. Whole-body potassium calculated from the count made during this 50-minute period gave a standard deviation of 3 to $4 \mathrm{~g}$. Values of potassium in $\mathrm{g} / \mathrm{kg}$ bodyweight were calculated and compared with those given as normal by Langham (1961) for children of the same age and sex.

Growth was investigated in three ways: length in relation to age; weight in relation to length; and skeletal age (Greulich-Pyle).

\section{Results}

Serum creatinine and electrolytes. The serum creatinine, sodium, and potassium concentrations remained normal in all cases. In 1971 there were no children with a raised serum chloride, but two (Cases 5 and 11, Table II) had a bicarbonate concentration below $20 \mathrm{mmol} / \mathrm{l}$, one (Case 5) having been on alkali supplements. By 1973 a raised serum chloride was found in 3 children (Cases 5, 11, and 13). Six children (Cases 3, 5, 8, 9, 10, and 11) had a lowered serum bicarbonate, 2 (Cases 5 and 11) showing a hyperchloraemic acidosis, of whom one was on alkali supplements. Of the 4 children with only a low serum bicarbonate 2 were on alkali supplements (Table II).

The benefit of alkali supplements is difficult to judge. Of 9 children who had taken them from the time of operation 6 had a normal serum bicarbonate in 1971 and 1973 and 2 had a lowered bicarbonate in 1973, having been normal in 1971. It was lowered in the remaining child on both occasions but less so in 1973 than in 1971. Of 2 children who were on alkali therapy in 1971 but not in 1973 one had a normal serum bicarbonate on both occasions while in the other it was lowered in 1973. Finally, 2 children who received no alkali had definitely low bicarbonate levels by 1973.

Although our data allow no firm conclusions, they suggest that alkali therapy probably does help to

\section{TABLE II}

Serum chloride and potassium levels in 13 children after ureterosigmoidostomy when seen at follow-up in 1971 and 1973

\begin{tabular}{|c|c|c|c|c|c|c|}
\hline \multirow{2}{*}{$\begin{array}{c}\text { Case } \\
\text { no. }\end{array}$} & \multicolumn{3}{|c|}{1971} & \multicolumn{3}{|c|}{1973} \\
\hline & $\underset{(\mathrm{mmol} / \mathrm{l})}{\mathrm{Cl}^{-}}$ & $\underset{(\mathrm{mmol} / \mathrm{l})}{\mathrm{HCO}_{3}^{-}}$ & $\begin{array}{l}\text { Alkali } \\
\text { supplements }\end{array}$ & $\underset{(\mathrm{mmol} / \mathrm{l})}{\mathrm{Cl}^{-}}$ & $\underset{(\mathrm{mmol} / \mathrm{l})}{\mathrm{HCO}_{3}^{-}}$ & $\begin{array}{c}\text { Alkali } \\
\text { supplements }\end{array}$ \\
\hline $\begin{array}{r}1 \\
2 \\
3 \\
4 \\
5 \\
6 \\
7 \\
8 \\
9 \\
10 \\
11 \\
12 \\
13\end{array}$ & $\begin{array}{l}102 \\
111 \\
104 \\
104 \\
105 \\
105 \\
104 \\
107 \\
108 \\
106 \\
102 \\
103 \\
108\end{array}$ & $\begin{array}{l}20 \cdot 1 \\
19 \cdot 5 \\
21 \cdot 6 \\
22 \\
16 \cdot 4 \\
21 \\
22 \\
21 \cdot 4 \\
21 \cdot 5 \\
20 \\
19 \\
22 \\
21\end{array}$ & $\begin{array}{l}+ \\
+ \\
+ \\
+ \\
+ \\
+ \\
+ \\
+ \\
+ \\
- \\
+ \\
+\end{array}$ & $\begin{array}{l}106 \\
109 \\
108 \\
109 \\
113 \\
107 \\
104 \\
102 \\
110 \\
103 \\
118 \\
107 \\
113\end{array}$ & $\begin{array}{l}22 \cdot 3 \\
22 \cdot 4 \\
10 \cdot 8 \\
24 \cdot 5 \\
18 \cdot 5 \\
21 \cdot 5 \\
21 \cdot 6 \\
15 \cdot 0 \\
14 \cdot 7 \\
16 \cdot 5 \\
13 \cdot 3 \\
21 \cdot 6 \\
21 \cdot 5\end{array}$ & $\begin{array}{l}+ \\
+ \\
+ \\
- \\
+ \\
+ \\
+ \\
+ \\
- \\
- \\
- \\
+ \\
+\end{array}$ \\
\hline
\end{tabular}


maintain normal serum bicarbonate levels and reduce the tendency to hyperchloraemic acidosis.

Intravenous pyelography. Of the 7 cases with a normal IVP in 1971 (Cases 1, 3, 5, 6, 7, 9, and 12) it was still normal in 1973, by which time the seventh (Case 12) had dilated ureters. In one child (Case 2), who before operation and again in 1971 had had radiological signs of bilateral mild pyelonephritis but normal ureters, both ureters were dilated in 1973. In Case 4, a previously dilated ureter was more dilated. The IVP in each of the 4 other children remained unchanged, with unilateral or bilateral mild dilatation of the ureters (Cases 8, 10, 11, and 13). Thus ureteric dilatation, as judged by IVP appearances, seems to develop with time (Table III).

Pyelonephritis. Two girls had recurrent symptoms of acute pyelonephritis. One of them (Case 2) had recognizable chronic pyelonephritis in 1971 and a dilated ureter developed in the two subsequent years. The other (Case 4 ) has been described above. One of these girls was on sulphonamide prophylaxis. Thus there were only 2 children with

\section{TABLE III}

Urogram appearances in 13 children after ureterosigmoidostomy performed between 1964-70

\begin{tabular}{c|c|c|c}
\hline $\begin{array}{c}\text { Date of } \\
\text { follow-up }\end{array}$ & Normal & $\begin{array}{c}\text { Hydro- } \\
\text { ureter }\end{array}$ & $\begin{array}{c}\text { Chronic } \\
\text { pyelo- } \\
\text { nephritis }\end{array}$ \\
\hline 1971 & 7 & 5 & 1 \\
1973 & 6 & 7 & 1 \\
\hline
\end{tabular}

clinical signs of pyelonephritis, both of whom had an abnormal IVP. We do not know if asymptomatic renal infection is present in the other 5 children with dilated ureters or in those with a normal IVP, because such infection cannot be detected in patients with a ureterosigmoidostomy.

Whole-body potassium. The observed values for whole-body potassium are shown in Table IV along with the normal values according to Langham (1961). The difference is expressed as a percentage of the normal value. Possible potassium depletion - that is, with a negative value for the differencewas recorded in 1971 in 9 children (3 girls and 6 boys) with body potassium 10-15\% below expected values. Yet most of these deficiencies had become much less or had disappeared by 1973, leaving only 3 children (Cases 10,11, and 12) with possible depletion. There was no correlation between serum bicarbonate concentrations and whole-body potassium values. There was no evidence that potassium supplements affected the total body content.

If we look critically at our figures and take into account that the counting statistics show standard deviations (SD) up to $12 \%$ and that normal values of potassium per $\mathrm{kg}$ bodyweight show SDs of 10-18\% (Allen, Anderson, and Langham, 1960; Langham, 1961; Novak et al., 1970; United Kingdom Atomic Energy Authority, 1964), none of the children had whole-body potassium values differing more than $2 \mathrm{SD}$ from the normal. Thus we found no evidence of significant shortage of body potassium.

Growth. Weight and length findings are shown in Figs. 1 and 2. The length/age curves were normal

TABLE IV

Whole-body potassium in 13 children after ureterosigmoidostomy when seen at follow-up in 1971 and 1973

\begin{tabular}{|c|c|c|c|c|c|c|}
\hline \multicolumn{4}{|c|}{1971} & \multicolumn{3}{|c|}{1973} \\
\hline $\begin{array}{l}\text { Case } \\
\text { no. }\end{array}$ & $\begin{array}{c}\text { Observed value } \\
(\mathbf{g} / \mathbf{k g})\end{array}$ & $\begin{array}{l}\text { Normal valuet } \\
(\mathbf{g} / \mathbf{k g})\end{array}$ & $\begin{array}{c}\text { Difference } \\
(\%)\end{array}$ & $\begin{array}{l}\text { Observed value } \\
(\mathbf{g} / \mathbf{k g})\end{array}$ & $\begin{array}{c}\text { Normal valuet } \\
(\mathbf{g} / \mathbf{k g})\end{array}$ & $\begin{array}{c}\text { Difference } \\
(\%)\end{array}$ \\
\hline $\begin{array}{l}1 \\
2^{\star} \\
3^{\star} \\
4 \\
5 \\
6 \\
7 \\
8 \\
9 \\
10 \\
11 \\
12^{\star} \\
13^{\star}\end{array}$ & $\begin{array}{l}2 \cdot 06 \\
1 \cdot 84 \\
1 \cdot 61 \\
2 \cdot 04 \\
2 \cdot 01 \\
2 \cdot 08 \\
2 \cdot 00 \\
1 \cdot 66 \\
1 \cdot 75 \\
2 \cdot 19 \\
1 \cdot 82 \\
2 \cdot 10 \\
1 \cdot 90\end{array}$ & $\begin{array}{l}2 \cdot 06 \\
2 \cdot 03 \\
1 \cdot 81 \\
1 \cdot 94 \\
2 \cdot 06 \\
1 \cdot 91 \\
2 \cdot 03 \\
1 \cdot 96 \\
2 \cdot 03 \\
1 \cdot 98 \\
1 \cdot 97 \\
2 \cdot 18 \\
2 \cdot 18\end{array}$ & $\begin{array}{c}0 \\
-9.4 \\
-11 \cdot 8 \\
+5 \cdot 1 \\
-2 \cdot 4 \\
+8 \cdot 9 \\
-1.5 \\
-15 \cdot 3 \\
-13 \cdot 8 \\
+10 \cdot 6 \\
-7 \cdot 6 \\
-3 \cdot 7 \\
-12.8\end{array}$ & $\begin{array}{l}2 \cdot 13 \\
2 \cdot 12 \\
2 \cdot 15 \\
2 \cdot 03 \\
2 y 07 \\
2 \cdot 20 \\
2 \cdot 15 \\
2 \cdot 04 \\
2 \cdot 08 \\
1 \cdot 89 \\
1 \cdot 93 \\
1 \cdot 82 \\
2 \cdot 17\end{array}$ & $\begin{array}{l}2 \cdot 17 \\
2 \cdot 16 \\
1 \cdot 96 \\
7 \cdot 84 \\
2 \cdot 18 \\
2 \cdot 08 \\
2 \cdot 18 \\
2 \cdot 11 \\
2 \cdot 18 \\
2 \cdot 13 \\
2 \cdot 12 \\
2 \cdot 04 \\
2 \cdot 04\end{array}$ & $\begin{array}{r}-1 \cdot 8 \\
-1 \cdot 8 \\
+9 \cdot 7 \\
+q 0 \cdot 3 \\
-5 \cdot 0 \\
+5 \cdot 8 \\
-1 \cdot 4 \\
-3 \cdot 3 \\
-4 \cdot 6 \\
-11 \cdot 3 \\
-9 \cdot 0 \\
-10 \cdot 8 \\
+6 \cdot 4\end{array}$ \\
\hline
\end{tabular}

$\star$ Received potassium supplements.

tLangham (1961). 


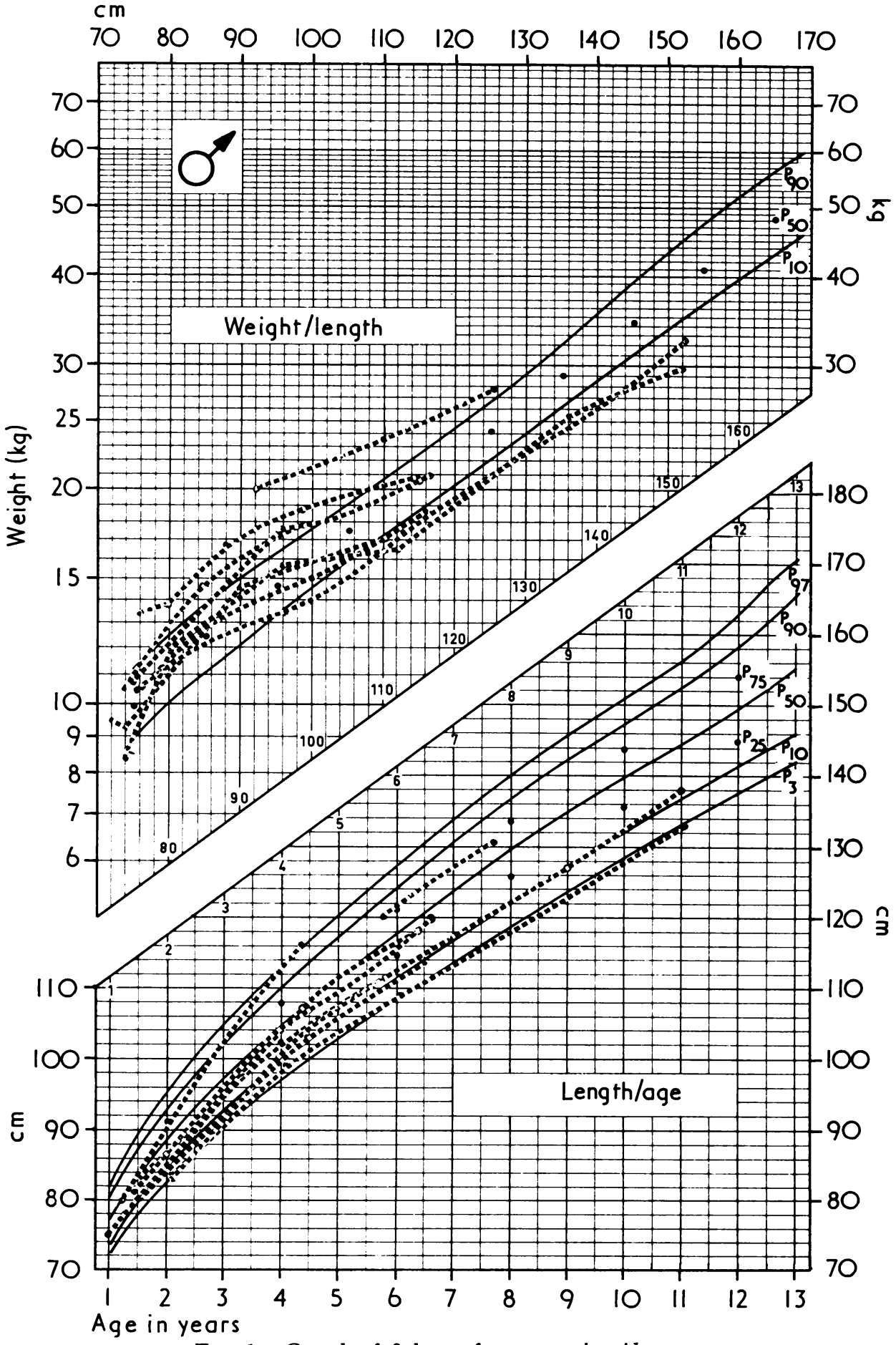

FIG. 1.-Growth of 8 boys after ureterosigmoidostomy. 


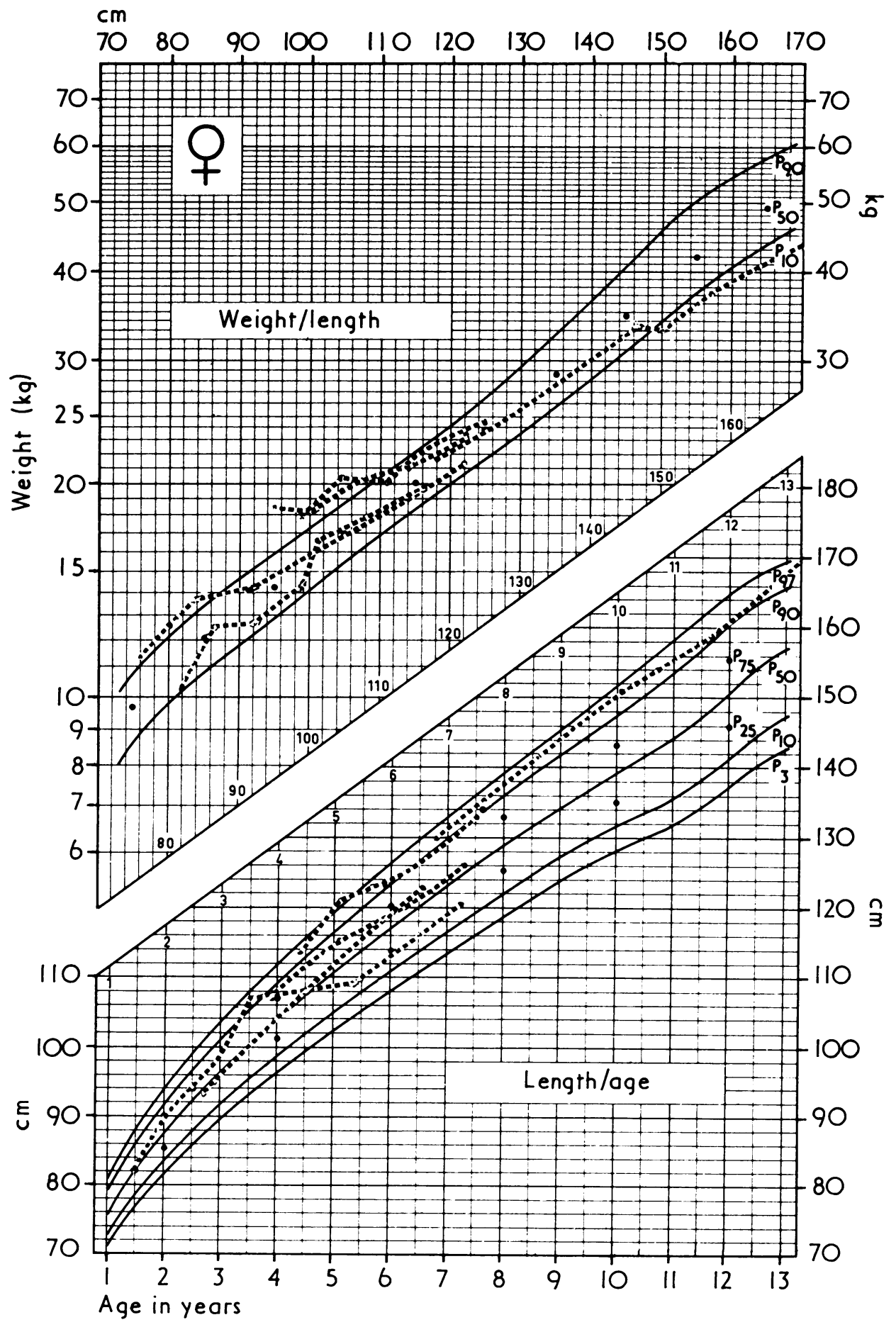

FIG. 2.-Growth of 5 girls after ureterosigmoidostomy. 
but the weight/length curves tended to decline from the normal. Bone age (which was kindly interpreted by Professor H. K. A. Visser) deviated from calendar age by more than one year-that is, by 2 SD-in 5 children (Cases 4, 7, 9, 10, and 12), although growth in all of these children was otherwise normal. We concluded therefore that they showed no evidence of growth retardation.

\section{Discussion}

We had to rely simply on the level of serum creatinine for assessing renal function, although quantitative renography may in future provide a better method of measurement.

Our main difficulty in monitoring these children has been the inability to detect asymptomatic urinary infection. The slow development of dilated ureters could well be a consequence of such an infection. Snell, Pursell, and Brumfitt (1973) suggest that serum antibody titres against Gramnegative organisms isolated from the voided rectal urine may help to diagnose renal infection in these patients, and at the same time identify the organism causing the infection and determine its antibiotic sensitivity.

Grüneberg, Smellie, and Leakey (1973) found in these cases that about $65 \%$ of the rectal flora becomes sulphonamide-resistant and $34 \%$ ampicillinresistant, whereas they tend to remain sensitive to nitrofurantoin, trimethoprim, and nalidixic acid. Perhaps, therefore, sulphonamides or ampicillin should not be given prophylactically to children with a ureterosigmoidostomy.

Ansell, Geist, and Creevy (1961) studied 4 children who had had a ureterosigmoidostomy, and they found whole-body potassium $25-40 \%$ below the normal values given by Corsa et al., (1956). These normal values for exchangeable potassium were obtained by isotope-dilution techniques with ${ }^{42} \mathrm{~K}$ derived from the specific urine activity in 16 convalescent hospitalized infants and children aged from 1 month to 15 years. The data, however, are unsatisfactory for applying to normal healthy children because the patients studied were all convalescing from a disease which had required hospitalization, and may well have had some muscle atrophy. Moreover, the isotope dilution technique is now known to be unreliable, since about $10 \%$ of the whole-body potassium exchanges very slowly in the red cells, brain, and bone. We decided to use whole-body counting data for normals as given by Langham (1961), who related body potassium to age and sex in 1590 individuals aged from 1 to 79 years.

Although there are difficulties in investigating possible potassium deficiency in children with a ureterosigmoidostomy, our findings are in agreement with those recently published by Boddy et al. (1975) for adults.

\section{REFERENCES}

Allen, T. H., Anderson, E. C., and Langham, W. H. (1960). Total body potassium and gross body composition in relation to age. fournal of Gerontology, 15, 348.

Ansell, J. S., Geist, R. W., and Creevy, C. D. (1961). Estimation of total body potassium in patients with ureterosigmoidostomies. Surgery, Gynecology, and Obstetrics, 112, 322.

Bakker, N. J., and Cornil, C. (1972). Techniques and complications of ureterosigmoidostomy and the uretero intestinal conduit. Problems in Paediatric Urology. Ed. by J. H. Johnston and R. J. Scholtmeyer. Excerpta Medica, Amsterdam.

Boddy, K., King, P. C., Stewart, W. K., and Fleming, L. W. (1975). Whole body potassium in patients with uretero-sigmoid anastomoses. British fournal of Urology, 47, 277.

Corsa, L., Jr., Gribetz, D., Cook, C. D., and Talbot, N. B. (1956). Total body exchangeable water, sodium and potassium in 'hospital normal' infants and children. Pediatrics, 17, 184.

Damme, K. J. van, and Barnhoorn, A. (1970). De "Whole-body monitor' te Leiden. Polytechnisch Tijdschrift, Editie B., 25, 14.

Grüneberg, R. N., Smellie, J. M., and Leakey, A. (1973). Changes in the antibiotic sensitivities of faecal organisms in response to treatment in children with urinary tract infection. Urinary Tract Infection. Ed. by W. Brumfitt and A. W. Asscher, p. 131. Oxford University Press, London.

Langham, W. H. (1961). Applications of whole-body liquid scintillation counters. Radio-activity in Man. Ed. by G. R. Meneely. p. 311 . Thomas, Springfield, Illinois.

Novak, L. P., Hamamoto, K., Orvis, A. L., and Burke, E. C. (1970). Total body pottassium in infants. American fournal of Diseases of Children, $119,419$.

Snell, M. E., Pursell, R., and Brumfitt, W. (1973). A method of determining of the most effective treatment for ureterosigmoidostomy patients with pyelonephritis. Urinary Tract Infection. Ed. by W. Brumfitt, and A. W. Asscher. p. 215 . Oxford University Press, London.

Spence, H. M. (1966). Ureterosigmoidostomy for exstrophy of the bladder. British fournal of Urology, 38, 36.

Stamey, T. A. (1956). The pathogenesis and implications of the electrolyte imbalance in ureterosigmoidostomy. Surgery, Gynecology and Obstetrics, 103, 736.

United Kingdom Atomic Energy Authority, Reactor Group (1964). $A$ Note on Potassium Contents of a Group of 154 People in Normal Health. Report $A E E W-M 391$. Atomic Energy Research Establishment, Winfrith.

Correspondence to Prof. N. J. Bakker, 's-Landswerf 256, Rotterdam-3016, the Netherlands. 